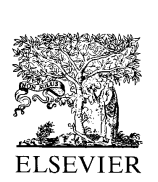

\title{
Inherited and Acquired Risk Factors and Their Combined Effects in Pediatric Stroke
}

\author{
Sameiro Barreirinho, MD*, Anabela Ferro, BSc ${ }^{\dagger}$, Manuela Santos, MD*, Elísio Costa, BSc ${ }^{*}$, \\ Jorge Pinto-Basto, $\mathrm{MD}^{\dagger}$, Alda Sousa, $\mathbf{P h D}^{\dagger \S}$, Jorge Sequeiros, $\mathbf{M D}, \mathbf{P h D}^{\dagger \S}$, \\ Patricia Maciel, PhD ${ }^{\dagger \S}$, Clara Barbot, MD*, and José Barbot, MD*
}

The aim of this study was to identify hereditary and acquired risk-factors as they are related to the occurrence of stroke in children. We identified 21 children with stroke. A search of the Factor V Leiden mutation, the Factor II G20210A variant, and the thermolabile variant of methylenetetrahydrofolate reductase was performed in patients and in a control group $(n=115)$.

We identified risk factors of acquired and/or hereditary nature for stroke in 19 of 21 children. Eleven children had three or more risk factors, seven had two risk factors, and one child had only one risk factor. We found three carriers $(\mathbf{1 4 . 3 \%})$ of the Factor $V$ Leiden mutation, two carriers $(9.5 \%)$ of the Factor II G20210A variant, eleven $(\mathbf{5 2 . 4 \%})$ thermolabile variant of methylenetetrahydrofolate reductase heterozygote carriers, and one $\mathbf{( 4 . 8 \%}$ ) homozygotes for this variant.

Frequencies of the Factor $V$ Leiden mutation and the Factor II variant were higher in patients than in controls, suggesting that these variants are associated with an increased risk of stroke in childhood. Homozygosity for the thermolabile variant of methylenetetrahydrofolate reductase was equally frequent amongst patients and controls.

Our study confirms that stroke in children is commonly associated with a combination of multiple risk factors, both genetic and acquired, and that the Factor V Leiden mutation and the Factor II G20210A variant are predisposing factors for this situation. (C) 2003 by Elsevier Inc. All rights reserved.

Barreirinho S, Ferro A, Santos M, Costa E, Pinto-Basto J, Sousa A, Sequeiros J, Maciel P, Barbot C, Barbot J. Inherited and acquired risk factors and their combined effects in pediatric stroke. Pediatr Neurol 2003;28:134-138.

From the *Serviço de Neuropediatria, Hospital de Crianças Maria Pia, Porto; ${ }^{\dagger}$ UnIGENe, Instituto de Biologia Molecular e Celular,

University Porto; ${ }^{\ddagger}$ Serviço de Hematologia, Hospital de Crianças

Maria Pia, Porto; ${ }^{\S}$ Department Estudos das Populações, ICBAS, Univ.

Porto, Portugal.

\section{Introduction}

Pediatric stroke is more common than previously thought [1]. Its overall incidence has been estimated to be 2.5 cases in 100,000 per year [2], with $44 \%$ to $61 \%$ of ischemic origin [2-4]. Awareness of etiologic factors is essential because recurrence is significant and disabilities are frequent, endangering quality of life $[1,5,6]$. Several conditions have been associated with stroke, including cardiac disease, vascular abnormalities, endothelial damage, infectious diseases, collagen tissue disease, and some inborn errors of metabolism and inherited or acquired coagulation abnormalities that predispose to thrombotic complications. Reported prothrombotic abnormalities include anticardiolipin antibody, lupus anticoagulant, deficiencies of protein $\mathrm{C}$, protein $\mathrm{S}$, antithrombin, and plasminogen [1,5-11]. New hypercoagulable states are being identified as risk factors for ischemic stroke in childhood: the presence of abnormal activated protein $\mathrm{C}$ resistance (or Factor V Leiden), Factor II G20219A variant, and thermolabile variant of methylenetetrahydrofolate reductase (MTHFR C677T) [8-13]. The knowledge of such abnormalities is important to define more rational prophylactic and therapeutic strategies.

The aim of this study was to identify thrombophilic conditions that might be related to the development of stroke in children.

\section{Patients and Methods}

This retrospective study included 21 children with ischemic stroke observed in the last 12 years (1987-1999) at Hospital de Crianças Maria Pia. Neonatal stroke, as well as patients presenting with transient symptoms, were excluded from this series. The diagnosis of cerebral ischemic stroke was confirmed in all patients by computerized tomography (CT) and/or magnetic resonance imaging (MRI) scans. Addition- 
ally, magnetic resonance angiography (MRA) was performed in three patients, standard angiography in four, and one child had MRA and standard angiography.

Data collected included age at diagnosis, sex, previous medical history, family history, signs and symptoms presented, radiologic findings, treatment, and outcome.

Baseline investigations performed at the time of diagnosis included complete blood count, blood sedimentation rate and/or C-reactive protein, liver-function tests, creatinine, blood urea nitrogen, electrolytes, total cholesterol, triglycerides, lipoprotein (a) [Lp(a)], VDRL, chest radiography, electrocardiogram, and echocardiogram. Serologic tests, immunologic profile, muscle biopsy, skin biopsy for fibroblast characterization, and evaluation of cerebrospinal fluid pyruvate and lactic acid levels were also performed when indicated to establish a specific etiology.

The thrombophilia investigation included prothrombin, activated thromboplastin, thrombin and reptilase times, plasma fibrinogen level, activity of protein $\mathrm{C}$, protein $\mathrm{S}$, antithrombin III and plasminogen, normalized activated protein $\mathrm{C}$ sensitivity ratio (n-APC-SR), total homocysteine plasma level, lupus anticoagulant, anticardiolipin, and anti- $\beta 2$ glycoprotein 1 antibodies.

DNA analysis, for detection of Factor V Leiden mutation, Factor II G20219A variant, and thermolabile variant of methylenetetrahydrofolate reductase, was performed both in patients and in a control population $(n=115)$ of Portuguese origin, matched by sex and region of origin to the patient sample. DNA from controls was obtained from anonymous Guthrie cards (newborn screening of phenylketonuria) by the Chelex method. DNA from patients was extracted from peripheral blood by standard methods. Identification of the Factor $\mathrm{V}$ Leiden mutation (G1691A) [5] and Factor II G20210A variant [6] was performed by polymerase chain reaction-restriction fragment length polymorphism (PCR-RFLP) with MnlI and HindIII, respectively. The MTHFR variant was assessed by PCR-RFLP with HinfI in the control population, and by sequencing (using the primer $5^{\prime}$; TGGGCCCCTCACCTGGATG3';) of the purified PCR fragments in patients.

Fisher's exact test was used to compare the frequency of risk genotypes in patients and in controls. Odds ratios, with a $95 \%$ confidence interval, were estimated as an approximation of relative risk, given the low frequency of risk factors. A $P$-value less than 0.05 was considered to be statistically significant.

\section{Results}

\section{Clinical Findings}

The main clinical findings of our patients are summarized in Table 1: 67 percent were female. The age range was two months to 13 years with a mean of 5.3 years. Ten patients had a prior medical history with conditions predisposing to stroke. Considering family history, only one child had a father with myocardial infarction by the age of 45 .

\section{Treatment and Outcome}

At the acute stage, treatment was only symptomatic. Heparin therapy was used in three patients: cases 6 and 7 had a corticosteroid dependent nephrotic syndrome, and case 8 had a cyanotic cardiac disease. Antiplatelet prophylaxis was instituted in eight patients (seven with aspirin and one with indobufene).

Total recovery was achieved by 11 patients $(52.4 \%)$. Persistent motor deficit (hemiparesis in seven patients and quadriparesis in two), symptomatic epilepsy (five patients), and cognitive impairment (seven patients) were the main sequelae observed. Five of the eight patients with seizures at the onset of stroke later developed epilepsy. Disabilities were as frequent in our patients (47.6\%) as reported by others [7]. Recurrence of stroke occurred in five patients $(23.8 \%)$, a frequency similar to previous reports $[5,11,14]$.

\section{Risk Factors}

Known risk factors for stroke were identified in 19 children (Table 1). Risk factors of a hereditary nature were identified in 10 patients, whereas acquired risk factors were found in 18 patients. Eleven patients $(52.4 \%)$ had three or more risk factors, seven (33.3\%) had two, and one (4.8\%) had only one. In two patients, no risk factors were identified.

All recurrences (cases 3, 8, 13, 16 and 18) occurred in children with identified risk factors (Table 1); these cases however had a longer follow-up than those without recurrences (10.5 vs 7 years).

Genotype distributions for the Factor V Leiden mutation, Factor II, and MTHFR variants are given in Table 2. Three of the 21 patients $(14.3 \%)$ were heterozygous for Factor V Leiden. Two patients $(9.5 \%)$ carried the Factor II G20210A variant. The T/T genotype at position 677 of MTHFR was present in one case (4.8\%). When compared with controls, the difference in allele frequencies at the Factor V and Factor II loci was not statistically significant ( $P=0.074$ and $P=0.064$, respectively), but exhibited a trend towards increased frequency of these variants amongst patients. Odds ratios were 4.63 (95\% CI: 0.95 22.40) and 11.79 (95\% CI: 1.02-136.52), suggesting that carriers of these variants have approximately 5 -fold and twelve-fold higher risks of developing stroke than noncarriers. Homozygosity for the MTHFR variant is equally frequent amongst patients and controls.

\section{Discussion}

A significant number of patients (90\%) in our series had one or more predisposing conditions for stroke. MRA and/or standard angiography was performed in just eight patients, and these studies would have identified additional risk factors. Only $10 \%$ did not have any recognizable risk factor, which is less than the $20-33 \%$ referred in literature $[1,2,5,11,12,15]$. This difference probably reflects different depths of investigation. The most frequent risk factor was the presence of antiphospholipid antibodies (62\%), as reported in other studies $[5,9,12,15]$. Increased $\mathrm{Lp}(\mathrm{a})$ was found in $29 \%$ of the children, which is also in agreement with recent reports that consider it as an important risk factor for spontaneous ischemic stroke in childhood $[12,13]$.

We have provided evidence that both Factor V Leiden mutation and Factor II G20210A variant have influence as risk factors for stroke in our pediatric population (relative risks of 4.63 and 11.79 , respectively). 


\begin{tabular}{|c|c|c|c|c|c|c|}
\hline \multirow[b]{2}{*}{ Patient } & \multirow[b]{2}{*}{ Sex } & \multirow{2}{*}{$\begin{array}{l}\text { Age at } \\
\text { stroke }\end{array}$} & \multirow[b]{2}{*}{ Presentation } & \multirow{2}{*}{$\begin{array}{c}\text { Infarct localization or } \\
\text { vascular } \\
\text { involvement }\end{array}$} & \multicolumn{2}{|l|}{ Risk factors } \\
\hline & & & & & Acquired & Inherited \\
\hline 1 & M & $5 \mathrm{yr} 5 \mathrm{mo}$ & $\begin{array}{l}\text { Cerebellar syndrome }(+\mathrm{L}) \\
\mathrm{R} \text { hemiplegia }\end{array}$ & $\begin{array}{l}\text { Bilateral cerebellar hemispheres } \\
(+\mathrm{L}) \text {, pontomesencephalic } \\
\text { transition }\end{array}$ & $\begin{array}{l}\text { Dissection vertebral artery, } \\
\text { cervical trauma, lupus } \\
\text { anticoagulant }\end{array}$ & $\begin{array}{l}\mathrm{Lp}(\mathrm{a})> \\
\quad 30 \mathrm{mg} / \mathrm{dl}\end{array}$ \\
\hline 2 & M & $6 y \mathrm{r}$ & $\begin{array}{r}\text { Cerebellar syndrome }(+\mathrm{R}), \\
\mathrm{R} \text { hemiplegia, cephalalgia }\end{array}$ & $\begin{array}{l}\mathrm{L} \text { pons, } \mathrm{R} \text { median cerebellar } \\
\text { peduncle, } \mathrm{L} \text { paramedian } \\
\text { occipital }\end{array}$ & $\begin{array}{l}\text { Dissection basilar artery, anti b2- } \\
\text { glycoprotein I Ab }\end{array}$ & \\
\hline \multirow[t]{4}{*}{3} & $\mathrm{~F}$ & $17 \mathrm{mo}$ & $\begin{array}{l}\mathrm{L} \text { amaurosis, } \mathrm{L} \text { ptosis, } \mathrm{L} \\
\text { hemiplegia }\end{array}$ & & & \\
\hline & & $5 \mathrm{yr} 2 \mathrm{mo}$ & L hemiplegia & & & \\
\hline & & $5 \mathrm{yr} 5 \mathrm{mo}$ & $\mathrm{R}$ hemiplegia, aphasia & & & \\
\hline & & $6 y r$ & Bilateral amaurosis & $\begin{array}{l}\text { Bilateral cerebral hemispheres, } \\
\text { retina }\end{array}$ & $\begin{array}{l}\text { Sneddon syndrome, anti- } \\
\text { cardiolipin } \mathrm{Ab}\end{array}$ & \\
\hline 4 & $\mathrm{~F}$ & $12 \mathrm{yr}$ & Seizures & Bilateral parietal + occipital & $\begin{array}{l}\text { Systemic lupus erythematosus, } \\
\text { anti-b2-glycoprotein I Ab }\end{array}$ & $\begin{array}{l}\mathrm{Lp}(\mathrm{a})> \\
\quad 30 \mathrm{mg} / \mathrm{dl}\end{array}$ \\
\hline 5 & $\mathrm{~F}$ & $12 \mathrm{yr} 10 \mathrm{mo}$ & Focal seizures & Bilateral frontal + occipital & $\begin{array}{l}\text { Systemic lupus erythematosus, } \\
\text { anti-b2-glycoprotein } 1 \mathrm{Ab} \text {, lupus } \\
\text { anticoagulant, } \\
\text { hyperhomocystinemia, } \\
\text { hyperlipidemia }\end{array}$ & \\
\hline 6 & $\mathrm{~F}$ & $6 y r 7 \mathrm{mo}$ & $\begin{array}{l}\text { Cephalalgia, vomiting, } \\
\text { convergent strabismus }\end{array}$ & LSS thrombosis & $\begin{array}{l}\text { Nephrotic syndrome, } \\
\text { hyperlipidemia, anticardiolipin } \\
\mathrm{Ab}\end{array}$ & \\
\hline 7 & M & $5 \mathrm{yr}$ & Cephalalgia, vomiting & $\begin{array}{l}\text { LSS thrombosis, L frontal }+ \\
\text { parietal }\end{array}$ & $\begin{array}{l}\text { Nephrotic syndrome } \\
\text { hyperlipidemia }\end{array}$ & FV Leiden \\
\hline \multirow[t]{2}{*}{8} & $\mathrm{~F}$ & $1 \mathrm{yr} 6 \mathrm{mo}$ & $\mathrm{R}$ hemiplegia, aphasia & & & \\
\hline & & $1 \mathrm{yr} 10 \mathrm{mo}$ & $\mathrm{L}$ hemiplegia & $\mathrm{R}$ temporoparietal & $\begin{array}{l}\text { Cyanotic cardiac disease, heart } \\
\text { surgery }\end{array}$ & \\
\hline 9 & M & $4 \mathrm{yr}$ & $\mathrm{L}$ hemiplegia & $\mathrm{R}$ pons & $\begin{array}{l}\text { Cyanotic cardiac disease, } \\
\text { anticardiolipin } \mathrm{Ab}\end{array}$ & $\begin{array}{l}\mathrm{Lp}(\mathrm{a})> \\
\quad 30 \mathrm{mg} / \mathrm{dl}\end{array}$ \\
\hline 10 & $\mathrm{~F}$ & $5 \mathrm{yr}$ & $\mathrm{L}$ hemiplegia & Basal ganglia & $\begin{array}{l}\text { Heart surgery, endocarditis, } \\
\text { hyperlipidemia, lupus } \\
\text { anticoagulant }\end{array}$ & \\
\hline 11 & $\mathrm{~F}$ & $1 \mathrm{yr} 11 \mathrm{mo}$ & L hemiplegia & Basal ganglia & Myocarditis, airways infection & \\
\hline 12 & $\mathrm{~F}$ & $4 \mathrm{yr} 6 \mathrm{mo}$ & Cephalalgia, amaurosis & Vertebrobasilar & $\begin{array}{l}\text { Chronic renal insufficency } \\
\text { hypertension, transitory systemic } \\
\text { hypotension, hyperlipidemia, } \\
\text { lupus anticoagulant }\end{array}$ & \\
\hline \multirow[t]{2}{*}{13} & $\mathrm{~F}$ & $7 \mathrm{yr}$ & $\mathrm{R}$ hemiplegia, & & & $\begin{array}{l}\text { Fanconi's } \\
\text { anemia, }\end{array}$ \\
\hline & & $7 \mathrm{yr} 1 \mathrm{mo}$ & L hemiplegia & Bilateral cerebral hemispheres & Hyperlipidemia, hypertension & $\begin{array}{l}\text { Moyamoya } \\
\text { syndrome }\end{array}$ \\
\hline 14 & M & $6 y r$ & $\mathrm{R}$ hemiplegia & L pons & Obesity & $\begin{array}{l}\text { FV Leiden, } \\
\text { Lp(a)> } \\
30 \mathrm{mg} / \mathrm{dl}\end{array}$ \\
\hline 15 & M & $1.5 \mathrm{mo}$ & Status epilepticus, coma & Bilateral cerebral hemispheres & Meningitis, anticardiolipin $\mathrm{Ab}$ & $\begin{array}{l}\text { FV Leiden, } \\
\text { Protein S } \\
\text { deficiency }\end{array}$ \\
\hline \multirow[t]{2}{*}{16} & M & $13 \mathrm{yr}$ & Seizures, coma & & & \\
\hline & & $13 \mathrm{yr}+3 \mathrm{mo}$ & Dystonia, tetraparesis & $\mathrm{R}$ cerebral hemisphere & Meningitis, anticardiolipin $\mathrm{Ab}$ & $\begin{array}{l}\mathrm{Lp}(\mathrm{a})> \\
\quad 30 \mathrm{mg} / \mathrm{dl}\end{array}$ \\
\hline 17 & $\mathrm{~F}$ & $2 \mathrm{mo}$ & Seizures & Bilateral cerebral hemispheres & & $\begin{array}{l}\text { FII variant } \\
\mathrm{Lp}(\mathrm{a})> \\
30 \mathrm{mg} / \mathrm{dl}\end{array}$ \\
\hline \multirow[t]{2}{*}{18} & $\mathrm{~F}$ & $13 \mathrm{mo}$ & L hemiplegia, seizures & $\mathrm{R}$ cerebral hemisphere & & \\
\hline & & $18 \mathrm{mo}$ & $\mathrm{R}$ hemiplegia, seizures & L parieto-occipital & $\begin{array}{l}\text { Airways infection, anticardiolipin } \\
\mathrm{Ab}\end{array}$ & FII variant \\
\hline 19 & $\mathrm{~F}$ & $18 \mathrm{mo}$ & $\mathrm{R}$ hemiplegia, seizures & Bilateral cerebral hemispheres & Anticardiolipin $\mathrm{Ab}$ & \\
\hline 20 & $\mathrm{~F}$ & $4 \mathrm{yr}$ & Seizures & $\mathrm{R}$ frontoparietal & & \\
\hline 21 & $\mathrm{~F}$ & $4 \mathrm{yr}$ & $\mathrm{R}$ hemiplegia & Basal ganglia & & \\
\hline $\begin{array}{l}\text { Abbrevia } \\
+\quad=1 \\
\mathrm{Ab}= \\
\mathrm{L}= \\
\mathrm{LSS}= \\
\mathrm{R} \quad=\end{array}$ & $\begin{array}{l}\text { ations: } \\
\text { Later } \\
\text { Antib } \\
\text { Left } \\
\text { Longi } \\
\text { Right }\end{array}$ & $\begin{array}{l}\text { l predominance } \\
\text { ody } \\
\text { tudinal superior }\end{array}$ & sinus & & & \\
\hline
\end{tabular}


Table 2. Genotype frequency of patients and controls. Shaded boxes indicate suspected risk genotypes; Data was grouped for analysis according to presence or absence of risk genotype

\begin{tabular}{|c|c|c|c|c|}
\hline \multirow[b]{2}{*}{ Genotype } & \multicolumn{2}{|c|}{ Observed Frequency (\%) } & \multirow[b]{2}{*}{$P^{\ddagger}$} & \multirow[b]{2}{*}{$\begin{array}{c}\text { Odds ratio } \\
(95 \% \mathrm{CI})\end{array}$} \\
\hline & $\begin{array}{l}\text { Patients } \\
(n=21)\end{array}$ & $\begin{array}{l}\text { Control group } \\
(n=115)\end{array}$ & & \\
\hline \multicolumn{5}{|c|}{ FV Leiden (G1691A) } \\
\hline $\mathrm{G} / \mathrm{G}$ & $18(85.7)$ & $111(96.5)$ & 0.074 & $4.63(0.95-22.40)$ \\
\hline G/A & $3(14.3)$ & $4(3.5)$ & & \\
\hline $\mathrm{A} / \mathrm{A}$ & $0(0)$ & $0(0)$ & & \\
\hline \multicolumn{5}{|c|}{ FII variant* (G20210A) } \\
\hline $\mathrm{G} / \mathrm{G}$ & $19(90.5)$ & $112(99.1)$ & 0.064 & $11.79(1.02-136.52)$ \\
\hline $\mathrm{G} / \mathrm{A}$ & $2(9.5)$ & $1(0.9)$ & & \\
\hline $\mathrm{A} / \mathrm{A}$ & $0(0)$ & $0(0)$ & & \\
\hline \multicolumn{5}{|l|}{ MTHFR $^{\dagger}(\mathrm{C} 677 \mathrm{~T})$} \\
\hline $\mathrm{C} / \mathrm{C}$ & $9(42.8)$ & $55(48.2)$ & 0.298 & $0.37(0.05-2.98)$ \\
\hline $\mathrm{C} / \mathrm{T}$ & $11(52.4)$ & $46(40.4)$ & & \\
\hline $\mathrm{T} / \mathrm{T}$ & $1(4.8)$ & $13(11.4)$ & & \\
\hline \multicolumn{5}{|c|}{$\begin{array}{l}*{ }^{\dagger \dagger}-\text { Two, one controls did not amplify, respectively } \\
*-2 \times 2 \text { Fisher's exact test }\end{array}$} \\
\hline
\end{tabular}

More importantly, however, stroke emerges as a condition associated with a combination of multiple risk factors, both inherited and acquired.

It is noteworthy that stroke recurrence occurred only in patients with recognizable risk factors, as reported by other series of patients $[5,11,12]$. This finding highlights the importance of their identification in the definition of prognosis and in the management decisions (treatment and secondary prophylactic measures).

The treatment of stroke in children has been primarily directed toward stabilizing systemic factors and managing underlying causes. No randomized, controlled treatment trials have been completed in children who suffered stroke. Many of the treatment approaches have been adapted from studies in adults, which include antithrombotic therapies (heparin, low molecular weight heparins, aspirin, warfarin, and thrombolytic agents), neuroprotective agents, and immunosuppressive therapy.

Accumulating experience with antithrombotic and anticoagulant treatment in children suggests that these agents can be used safely, although their efficacy and proper dose still need to be established. Low molecular weight heparin is increasingly used as the first choice for acute anticoagulant therapy in children with arterial ischemic stroke (AIS); its indications include arterial dissection, coagulations disorders, embolism from the heart (usually complex congenital heart disease), and children with progressive or additional neurologic deficits not caused by cerebral hemorrhage during the initial evaluation of a new cerebral infarction. Aspirin is frequently used as the treatment of choice for secondary prevention of AIS in situations of increased risk of recurrence such as cerebral arterial stenosis. Currently, most older children with AIS are placed on aspirin even when no cause is identified because of the risk of recurrence and minimal side effects. Major uses of warfarin treatment in children include congenital or acquired heart disease, severe hypercoagulable states, arterial dissection, and recurrent AIS or transient ischemic attacks while on aspirin $[11,15]$. In our study, none of the patients treated with heparin and/or aspirin had recurrence, but the restricted number of the cases limits the conclusion. Large controlled clinical trials are required to establish the role of antithrombotic and other therapies.

In conclusion, our study confirms that stroke in children is associated with a combination of predisposing conditions, genetic and acquired, often with the presence of multiple risk factors.

The most important risk factors identified were antiphospholipid antibodies and increased lipoprotein (a). The Factor V Leiden mutation and Factor II G20210A variant seem to be relevant predisposing factors for stroke in children of our study. Further analysis of these risk factors in larger series of pediatric patients would contribute to validate these findings. The fact that recurrence occurred only in children with identified risk factors suggests that identification of these factors should be considered for the management of such cases.

We would like to thank the patients and families for their collaboration in this study, and Drs. Rui Vaz Osório and Laura Vilarinho at Instituto de Genética Médica Jacinto Magalhães for providing the anonymous Guthrie cards used as controls in this study. This work was supported by Comissão de Fomento da Investigação em Cuidados de Saúde, Ministério da Saúde, Portugal. Anabela Ferro is the recipient of a Ph.D. scholarship by Fundação para a Ciência e Tecnologia, MCT, Portugal.

\section{References}

[1] Riela A, Roach E. Etiology of stroke in children. J Child Neurol 1993;8:201-20.

[2] Schoenberg B, Mellinger J, Schoenberg D. Cerebrovascular disease in infants and children: A study of incidence, clinical features and survival. Neurology 1978;28:763-8.

[3] Eeg-Olofsson O, Ringheim Y. Stroke in children: Clinical characteristics and prognosis. Acta Neurol Scand 1983;72:391-5. 
[4] Giroud M, Lemesle M, Gouyon JB, Nivelon JL, Milan C, Dumas R. Cerebrovascular disease in children under 16 years of age in the city of Dijon, France: A study of incidence and clinical features from 1985 to 1993. J Clin Epidemiol 1995;48:1343-8.

[5] Mancini J, Girard N, Chabrol B, et al. Ischemic cerebrovascular disease in children: Retrospective study of 35 patients. J Child Neurol 1997;12:193-9.

[6] Dubreuil Lastrucci DBM, Dawson DA, Munster M. Development of an internal restriction control in the PCR detection of the prothrombin 20210A mutation. Clin Lab Haem 1999;21:281-3.

[7] Satoh S, Shirane R, Yoshimoto T. Clinical survey of ischemic cerebrovascular disease in children in a district of Japan. Stroke 1991; 22:586-9.

[8] Lawson S, Butler D, Enayat M, Williams M. Congenital thrombophilia and thrombosis: A study in a single centre. Arch Dis Child 1999;81:176-8.

[9] Andrews P, Ryan M, Kandt R. Genetic causes of pediatric stroke. In: Alberts M, ed. Genetics of cerebrovascular disease. New York: Futura Publishing Company, 1999:261-311.
[10] Simioni P, Ronde H, Prandoni P, Saladini M, Bertina R, Girolami A. Ischemic stroke in young patients with activated protein $\mathrm{C}$ resistence. A report of three cases belonging to three different kindreds. Stroke 1995;26:885-90.

[11] deVeber G. Cerebrovascular disease in children. In: Swaiman K, Ashwai S, eds. Pediatric neurology, principles \& practice. St. Louis: Mosby, 1999:1099-124.

[12] Balasa V, Gruppo R, DeGrauw A. Pediatric stroke and thrombophilia: A retrospective study [abstract]. J Pediatr Hematol Oncol 1998;20:370

[13] Nowak-Gottl U, Strater R, Heinecke A, et al. Lipoprotein (a) and genetic polymorphisms of clotting factor $\mathrm{V}$, prothrombin and metylenetetrahydrofolate reductase are risk factors of spontaneous ischemic stroke in childhood. Blood 1999;94:3678-82.

[14] Riikonen R, Santavuori P. Hereditary and acquired risk factors for childhood stroke. Neuropediatrics 1994;25:227-33.

[15] Andrew M, Monagle PT, Brooker L. Stroke. In: Andrew M, Monagle PT, Brooker L, eds. Thromboembolic complications during infancy and childhood. London: BC Decker Inc., 2000:201-29. 